\title{
多機能磁性ナノ粒子の合成とバイオ医療分野への応用
}

\author{
前之園 信 也 \\ 北陸先端科学技術大学院大学 焉 923-1292 石川県能美市旭台 1-1
}

(2016年 7 月 26 日受付；2016 年 9 月 5 日掲載決定)

\section{Synthesis and Biomedical Applications of Multifunctional Magnetic Nanoparticles}

\author{
Shinya MAenosono
}

Japan Advanced Institute of Science and Technology, 1-1 Asahidai, Nomi, Ishikawa 923-1292

(Received July 26, 2016 ; Accepted September 5, 2016)

\begin{abstract}
Magnetic nanoparticles (MNPs) have become readily available thanks to the development of a range of synthetic techniques. In addition, various multifunctional hybrid MNPs have been recently developed for biomedical applications. We review the progress of research on biomedical multifunctional MNPs.
\end{abstract}

KEYWORDS : magnetic nanoparticle, biomedicine, magnetic separation, bioimaging, plasmon scattering

\section{1.は じめに}

これまで, MRI 造影剤, バイオマーカー検出プロー ブ, 磁気ハイパーサーミアの発熱体など, 磁性ナノ粒子 のバイオ医療分野での様々な応用が検討され，一部実用 化されている。近年益々バイオ医療分野における磁性ナ ノ粒子の需要が高まっており, 用途の拡大に伴って, 磁 性に加えてイメージング機能を併有することが望まれて いる。たとえばMa らは, 疎水性酸化鉄ナノ粒子の表面 をポリエチレングリコール修飾ホスホエタノールアミン で被覆し, その疎水領域へ蛍光色素を担持させた磁性蛍光ハイブリッドナノ粒子を作製し，がんのデュアルモ ードイメージングと光熱治療に有効であることを示し た ${ }^{1)}$ 。Mackay らは, コロイダル量子ドットと酸化鉄ナ ノ粒子を複合化した粒子がマルチモーダルバイオイメー

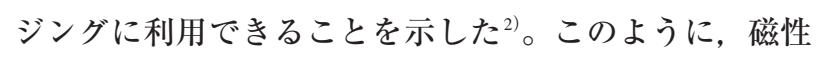
ナノ粒子にイメージング機能を持たせる手段としては, 蛍光色素分子や量子ドットと複合化させる方法が一般的 である ${ }^{3,4)}$ 。しかし蛍光色素は耐光性が低いため退色し やすく ${ }^{5)}$, 量子ドット (単一粒子の場合) は蛍光明滅現 象 ${ }^{6}$ を示すため, いずれも長時間イメージングには向か ない。

E-mail : shinya@jaist.ac.jp
$\mathrm{Au}$ や $\mathrm{Ag}$ などの貴金属ナノ粒子は, 局在表面プラズ モン共鳴（localized surface plasmon resonance, LSPR）に 由来する光学的性質によって, バイオイメージングや生 体分子センシングに利用されてきた ${ }^{7,8)}$ 。LSPR を利用し たイメージングは退色や明滅がなく, 安定した長時間観 察が可能である。したがって, 磁性材料とプラズモン材 料を複合化した磁性ープラズモンハイブリッドナノ粒子 は次世代の多機能磁性ナノ粒子として有望であり, いく

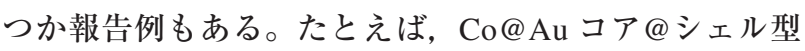
ナノ粒子9), $\mathrm{Au}-\mathrm{Fe}_{3} \mathrm{O}_{4}$ ヘテロダイマーナノ粒子 ${ }^{10)}$, $\mathrm{Au}-\mathrm{Fe}_{3} \mathrm{O}_{4}$ コアーサテライト型ナノ粒子 ${ }^{11)}, \mathrm{FePt}-\mathrm{Au}$ ヘテ ロダイマーナノ粒子 ${ }^{12}$ などである。我々は, 磁性材料の 中でも最も高い飽和磁化を持つ $\mathrm{FeCo}^{13)}$ と, プラズモン 材料の中でも最も高い LSPR 散乱断面積を持つ $\mathrm{Ag}^{14)}$ を 複合化させることを考えた。FeCo と Ag を複合化させ た磁性一プラズモンハイブリッドナノ粒子の既往の研究 例としては, 我々の知る限り, Sachan らのパルスレー ザーディウェッティング法による $\mathrm{Fe}_{8} \mathrm{Co}_{92}-\mathrm{Ag}$ ヘテロダ イマーナノ粒子の合成例 ${ }^{15)}$ みであり，化学合成による $\mathrm{FeCo}-\mathrm{Ag}$ 複合ナノ粒子の作製例はない。化学合成法は, パルスレーザー法などの真空中での物理的作製法やその 他の気相法に比べ, 均一なナノ粒子を大量に合成でき る, 複雑な構造のナノ粒子を容易に作製できる, ナノ粒 子表面に望みの配位子を結合させることができ機能化し 
やすい，などの様々なメリットがあるため, 我々は $\mathrm{FeCo}-\mathrm{Ag}$ 複合ナノ粒子の化学合成を試みた。

本稿では, $\mathrm{FeCo}$ と Ag からなる $\mathrm{Ag} @ \mathrm{FeCo} @ \mathrm{Ag}$ ダブ ルシェル型ナノ粒子の化学合成法とその物性について概 説した後, 細胞内小胞のイメージングと磁気分離への応 用の可能性について紹介する。 $\mathrm{Ag} @ \mathrm{FeCo} @ \mathrm{Ag}$ ダブルシ エル型構造を採用した理由は以下のとおりである。 $\mathrm{FeCo}-\mathrm{Ag}$ 複合ナノ粒子として最も単純な構造は $\mathrm{FeCo} @ \mathrm{Ag}$ コア@シェル型ナノ粒子だが, FeCo ナノ粒子 の表面を $\mathrm{Ag}$ シェルで被覆することは案外難しい。なぜ なら, $\mathrm{FeCo}$ ナノ粒子が酸化され, 格子不整合によって $\mathrm{Ag}$ シェルがうまく形成できなかったり, $\mathrm{FeCo}$ ナノ粒子 の表面に $\mathrm{Ag}$ イオンが近づくとガルバ二置換反応による $\mathrm{FeCo}$ のエッチングが起きたりするためである。上記の 問題を解決するため, 逆構造である $\mathrm{Ag} @ \mathrm{FeCo}$ コア@シ エル型磁性-プラズモンハイブリッドナノ粒子を合成し

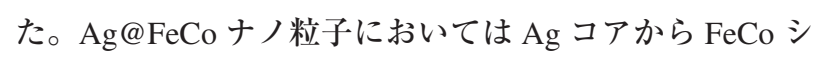
エルへの電子移動によって FeCo の酸化が抑制されるた め, $\mathrm{FeCo} シ ェ ル の$ 表面を $\mathrm{Ag}$ シェルで被覆した $\mathrm{Ag} @ \mathrm{FeCo} @ \mathrm{Ag}$ ダブルシェル型にすることが可能とな る ${ }^{16)} \mathrm{Ag}$ シェルの存在によって, $\mathrm{FeCo}$ の酸化がさらに 抑制されるほか, チオール基と $\mathrm{Ag}$ との結合を利用する ことで配位子交換が容易になるという利点もある。

\section{2. 多機能磁性ナノ粒子の化学合成}

\section{1 試薬}

コバルト(II)アセチルアセトナート $\left[\mathrm{Co}(\mathrm{acac})_{2}\right.$, 純度 $\geq 97 \%]$, 鉄(III) アセチルアセトナート $\left[\mathrm{Fe}(\mathrm{acac})_{3}\right.$, 純 度 $\geq 99.9 \%$ ，硝酸銀（ $\mathrm{AgNO}_{3}$, 純度 $\left.\geq 99.9999 \%\right), 1,2-$ ヘキサデカンジオール, 無水コハク酸, オレイルアミン (OLA, 純度 70\%), オレイン酸 (OA, 純度 90\%), テ トラエチレングリコール（TEG, 純度 99\%）は SigmaAldrich 社から購入し, そのまま使用した。と-ポリリジ
ン（PLL）と2-イミノチオランは，それぞれ JNC 株式 会社および Toronto Research Chemicals 社から購入した。

\section{$2.2 \mathrm{Ag} @ \mathrm{FeCo} @ \mathrm{Ag}$ ダブルシェル型ナノ粒子の合成}

Fig.1にAg@FeCo@Ag ダブルシェル型（コア@シェ ル@シェル型）ナノ粒子の合成スキームを示す ${ }^{16)}$ 。まず 室温で三ロフラスコに $\mathrm{AgNO}_{3}(0.1 \mathrm{mmol}), 1,2$-ヘキサ デカンジオール $(1.0 \mathrm{mmol})$, OLA $(10 \mathrm{mmol})$, OA (8 $\mathrm{mmol}), \mathrm{TEG}(10 \mathrm{~mL})$ を仕込み, 側管をセプタムで密 栓することによってフラスコ内を半密閉系とし, 擋找し ながら Ar バブリングを 5 分間行った。 Ar バブリングを 継続しながら, 反応溶液の温度を $100^{\circ} \mathrm{C}$ まで昇温し 10 分間摚找した後 $170^{\circ} \mathrm{C}$ まで昇温した。反応温度が $170^{\circ} \mathrm{C}$ に到達した直後, あらかじめ用意しておいた $\mathrm{Co}$ と $\mathrm{Fe}$ の前駆体溶液を静かにフラスコ内ヘシリンジを用いて注 入した。この前駆体溶液の組成は Co $(\mathrm{acac})_{2} \quad(0.2$ $\mathrm{mmol}), \mathrm{Fe}(\mathrm{acac})_{3}(0.2 \mathrm{mmol})$, OLA $(1 \mathrm{~mL})$, トルエン $(2 \mathrm{~mL})$ である。前駆体注入後, 反応温度を $250^{\circ} \mathrm{C}$ まで 上げ, $\mathrm{Ag}$ 前駆体溶液を再度注入した。 $\mathrm{Ag}$ 前駆体溶液の 組成は $\mathrm{AgNO}_{3}(0.1 \mathrm{mmol})$, OLA (1 mL), トルエン (1 $\mathrm{mL}$ ）である。 $\mathrm{Ag}$ 前駆体溶液注入後, 反応温度 $230^{\circ} \mathrm{C}$ で 10 分間反応させた。反応終了後, 反応溶液を自然冷却 し, アセトンを加えて遠心分離を行った。遠心分離後上 澄みを捨て, ヘキサンを加えナノ粒子を再分散させた 後, 再度アセトンを加えて遠心分離を行った。得られた ナノ粒子は, 風乾した後真空乾燥機で乾燥させた。

\subsection{PLL 表面修飾剤の合成と配位子交換}

合成直後の $\mathrm{Ag} @ \mathrm{FeCo} @ \mathrm{Ag}$ ダブルシェル型ナノ粒子の 表面は OLA で被覆されており疎水性であるため, 無極 性溶媒にしか分散しない。バイオ医療分野で利用するた めには, 水溶性かつ生体適合性の高い表面修飾剤に置換 する必要がある。そこで我々はホモポリアミノ酸である PLLに着目し，PLLをべースとした表面修飾剤を合成 し, 配位子交換によって OLA と置換してナノ粒子を水

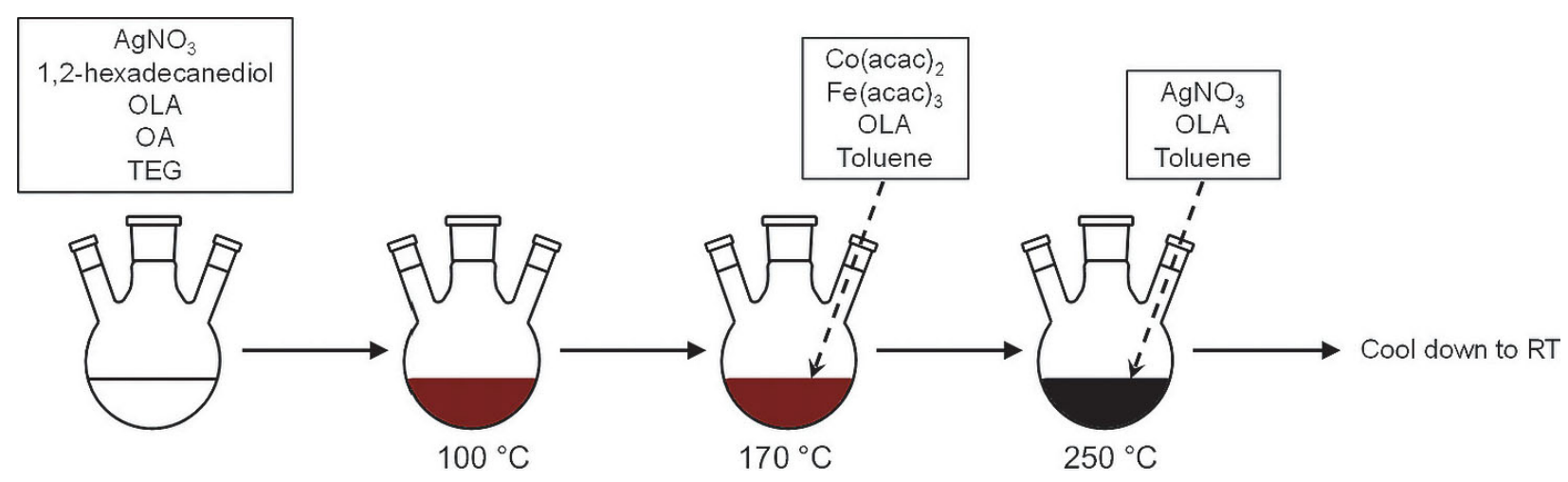

Fig. 1. (color online). Synthesis scheme of Ag@FeCo@Ag core@shell@shell nanoparticles (NPs). 
溶化した ${ }^{16)}$ 。PLL 表面修飾剤は以下の手順で合成した。 まず PLLの一部のアミノ基に無水コハク酸を反応させ てカルボキシル $(\mathrm{COOH})$ 基を導入し, 雨性高分子を合 成した ${ }^{17)}$ 。続いて，2-イミノチオランを反応させてチオ ール（SH）基を導入した。得られたポリマー（PLLCOOH-SH）は透析を 2 日間行った後, 凍結乾燥を 2 日 間行った。 $\mathrm{COOH}$ 基と $\mathrm{SH}$ 基の導入量は核磁気共鳴 (nuclear magnetic resonance, NMR) スペクトルから見積 もった。Fig. 2a，bに代表的な PLL 表面修飾剤の構造 と ${ }^{1} \mathrm{H}$ NMR スペクトルを示す。

配位子交換は以下の手順で行った。まず $15 \mathrm{mg}$ の PLL-COOH-SH を $1 \mathrm{~mL}$ の超純水に溶解し, エタノール $100 \mu \mathrm{L}$ を添加した。水酸化ナトリウムを添加すること でPLL 水溶液の $\mathrm{pH}$ が 12 となるよう調節した。次に, $\mathrm{Ag} @ \mathrm{FeCo} @ \mathrm{Ag}$ ナノ粒子をへキサンに分散し，このナノ 粒子分散液 $200 \mu \mathrm{L}$ を PLL 水溶液と混合して超音波を印 加し, 超音波印加中に純水 $2 \mathrm{~mL}$ を加えた。超音波印加 終了後, 40,000 rpm で 3 分間遠心分離を行い, 上澄みを 捨て, 沈殿物に超純水を少量加えて再分散させた。Fig. 2c に PLL-COOH-SH 修飾 Ag@ $\mathrm{FeCo} @ \mathrm{Ag}$ ナノ粒子水分 散液の写真を示す。PLL-COOH-SH 修飾によって $\mathrm{Ag} @ \mathrm{FeCo} @ \mathrm{Ag}$ ナノ粒子の水分散性が高まったことがわ かる。

\section{$2.4 \mathrm{Ag} @ \mathrm{FeCo} @ \mathrm{Ag}$ ダブルシェル型ナノ粒子の構造}

Fig. 3 に合成直後の $\mathrm{Ag} @ \mathrm{FeCo} @ \mathrm{Ag}$ ナノ粒子の透過電 子顕微鏡（transmission electron microscope, TEM）像, 高 分解能 TEM（high-resolution TEM, HR-TEM）像, 高角 散乱環状暗視野走查 TEM (high angle annular dark fieldscanning TEM, HAADF-STEM） 像, エネルギー分散型 X 線分光 (energy dispersive X-ray spectroscopy, EDS) 元素 マッピング像を示す。TEM 像から粒径分布解析をした 結果, ナノ粒子の平均粒径は $13.5 \pm 2.5 \mathrm{~nm}$ であった。 HAADF-STEM 像では, 輝度は㧍上そ原子番号の二乗 $\left(\mathrm{Z}^{2}\right)$ に比例するため, $\mathrm{Ag} コ ア は \mathrm{FeCo}$ シェルより明る く見える（Fig.3d-f）。また， EDS マッピングから，Ag

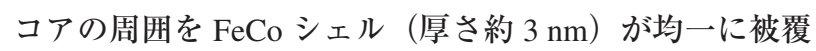
していることがわかる (Fig. 3g-r)。

また，単一ナノ粒子の EDS ラインプロファイルの詳 細な解析から, 薄い $\mathrm{Ag}$ シェルが $\mathrm{FeCo}$ シェルの表面に 存在することが確認され ${ }^{16)}, \mathrm{Ag} @ \mathrm{FeCo} @ \mathrm{Ag}$ ダブルシェ ル型ナノ粒子が得られていることがわかる。また, $\mathrm{FeCo}$ シェルの平均組成はほぼ $\mathrm{Fe}: \mathrm{Co}=1: 1$ であるもの

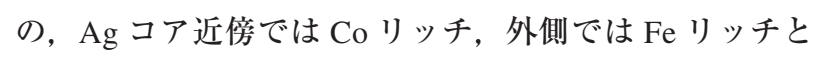
いう傾斜組成を有していることがわかった。

超伝導量子干渉磁束計 (superconducting quantum interference device, SQUID）によってこのナノ粒子の磁化特
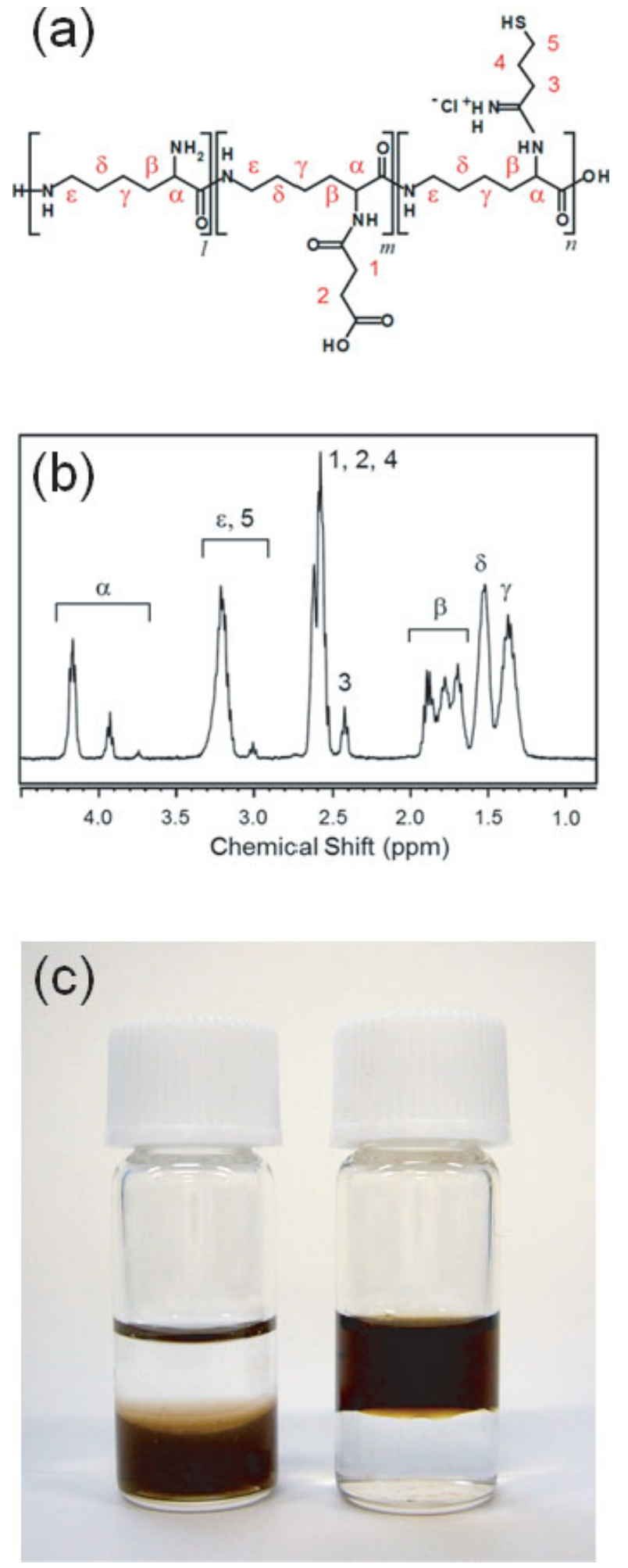

Fig. 2. (color online). (a) Structure and (b) ${ }^{1} \mathrm{H}$ NMR spectrum of PLL-COOH-SH polymer. (c) Photograph of dispersions of Ag@FeCo@Ag NPs before (right) and after (left) the ligand exchange. Upper and lower phases are hexane and water, respectively. 

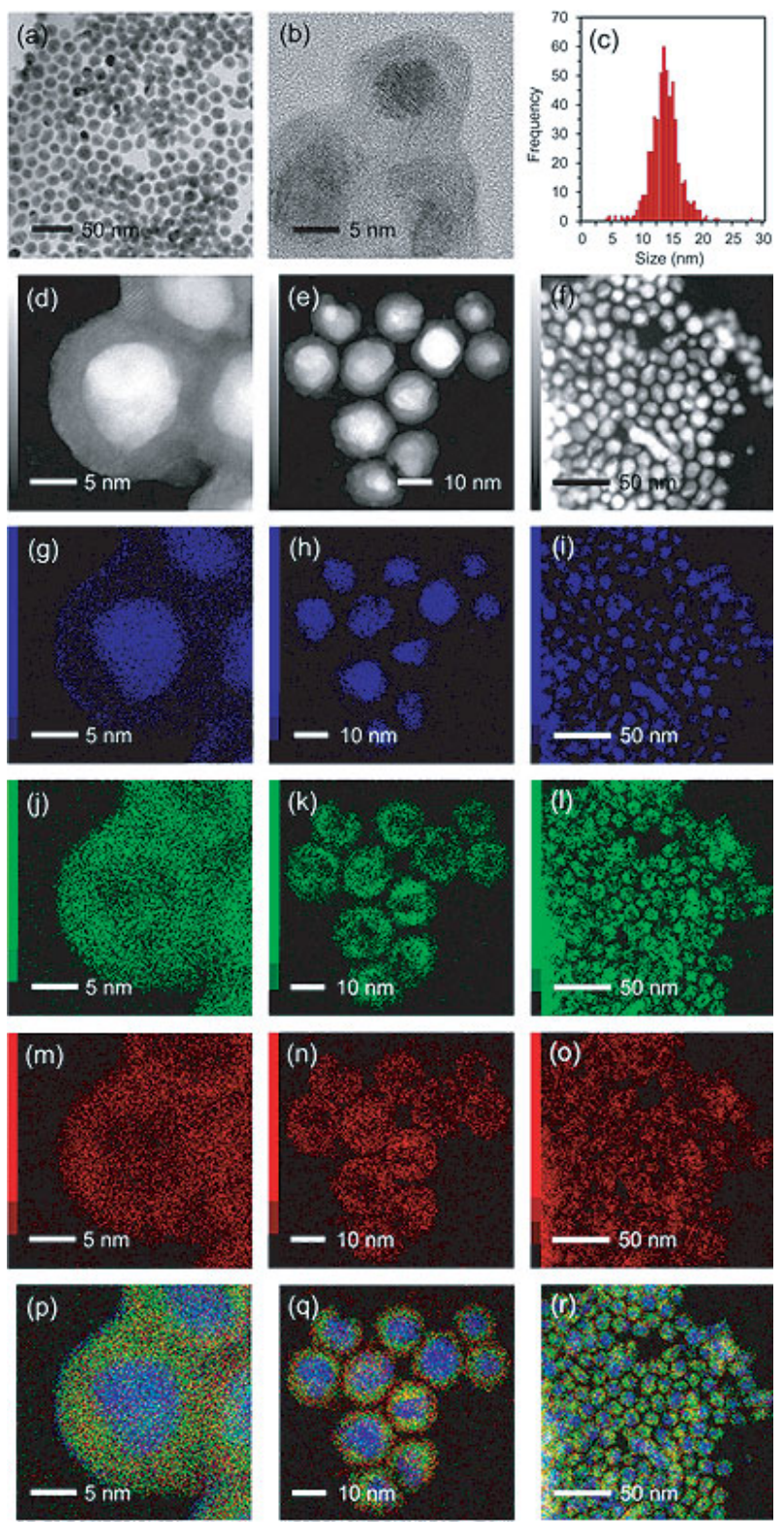

Fig. 3. (color online). (a) TEM image, (b) HR-TEM image, (c) size distribution, and (d-f) HAADF-STEM images of Ag@FeCo@Ag NPs. (g-r) EDS elemental mapping images of the Ag@FeCo@Ag NPs : (g-i) Ag L edge, (j-1) Co K edge, (m-o) Fe K edge, and (p-r) overlaid images.

性を評価した結果, 室温では超常磁性を示し, 飽和磁化 は $36.4 \mathrm{emu} / \mathrm{g}$ であった（Fig. 4a）。 Ag は反磁性体であ るので, $\mathrm{FeCo}$ シェルのみの磁化として換算すると 45.7 $\mathrm{emu} / \mathrm{g}\left(372 \mathrm{emu} / \mathrm{cm}^{3}\right)$ となり, 同じ体積の酸化鉄ナノ 粒子と比べて大きな飽和磁化を有している。Fig. 4bに 示すように, PLL-COOH-SH 修飾した $\mathrm{Ag} @ \mathrm{FeCo} @ \mathrm{Ag} ナ$ ノ粒子では飽和磁化が $19.2 \mathrm{emu} / \mathrm{g}$ まで低下するが, こ れはナノ粒子表面が分子量の大きい PLL-COOH-SH で 被覆されていることと,ナノ粒子に配位していない
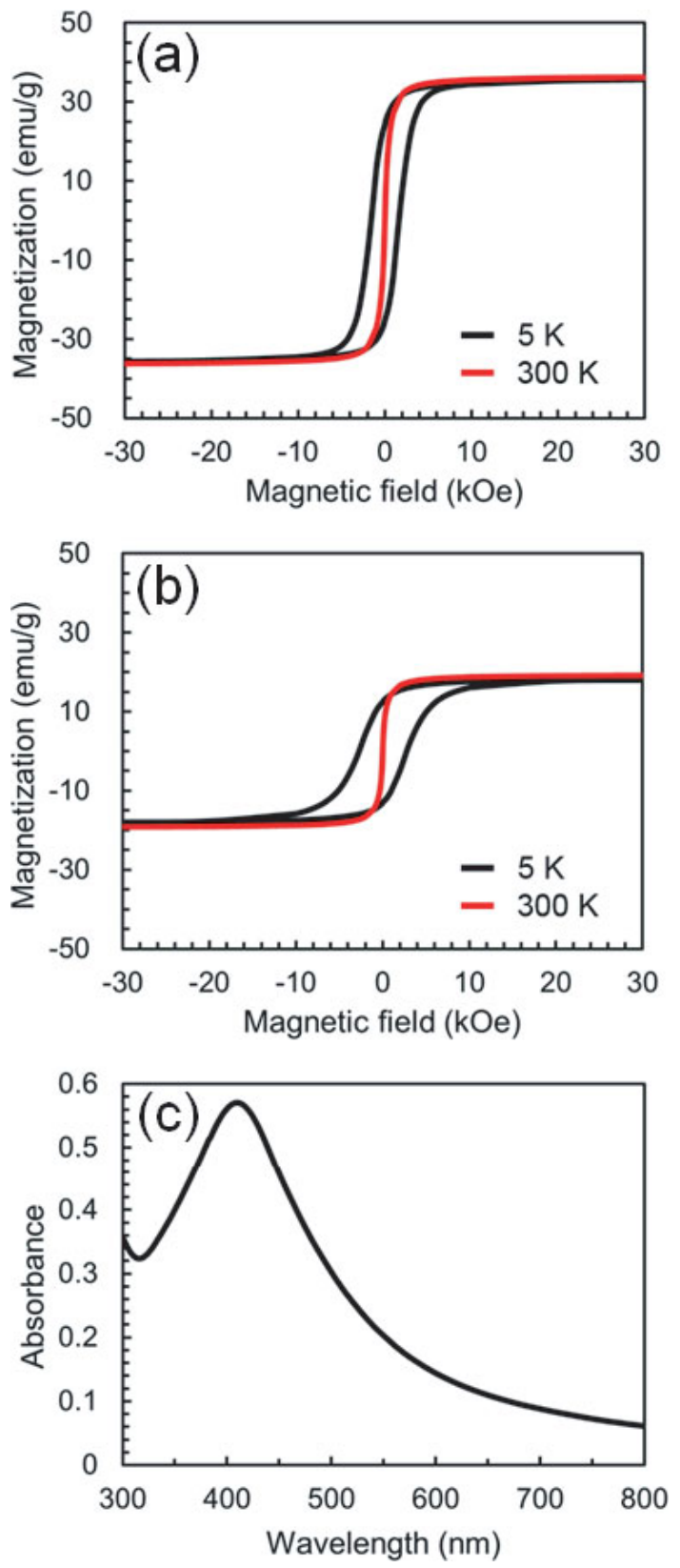

Fig. 4. (color online). Magnetization curves of (a) assynthesized and (b) PLL-COOH-SH-modified NPs measured at 5 and $300 \mathrm{~K}$. (c) UV-Vis spectrum of a hexane dispersion of as-synthesized NPs.

PLL-COOH-SH がサンプル中に少量残留していたことに よる。また, 紫外可視分光法 (ultraviolet-visible spectroscopy, UV-Vis）によって得られた $\mathrm{Ag} @ \mathrm{FeCo} @ \mathrm{Ag}$ ナノ粒 子の吸収スペクトルには Ag コア由来の LSPR バンドが $410 \mathrm{~nm}$ 付近に明確に観察できる (Fig. 4c)。したがっ て, $\mathrm{Ag} @ \mathrm{FeCo} @ \mathrm{Ag}$ ナノ粒子は, 超常磁性と LSPR 特性 を兼ね備えたハイブリッドナノ粒子であることが確認さ れた。 

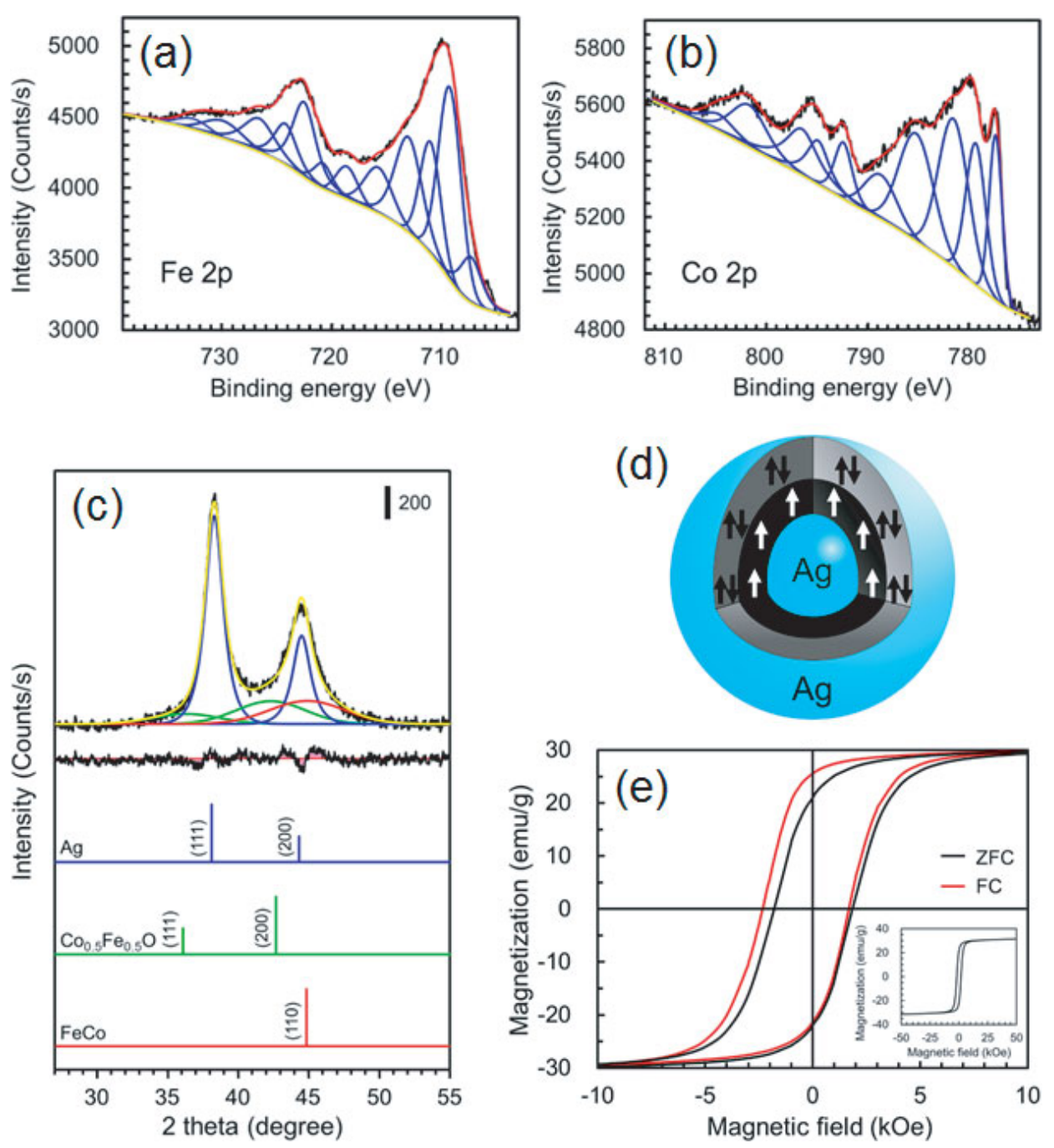

Fig. 5. (color online). (a) Fe 2p and (b) Co 2p core-level XPS spectra, and (c) XRD pattern of Ag@FeCo@Ag NPs. Peaks were deconvoluted into $f c c$ Ag (JCPDS PDF No. 01-087-0717), bcc FeCo (JCPDS PDF No. 00-049-1567) and $\mathrm{Co}_{0.5} \mathrm{Fe}_{0.5} \mathrm{O}$ phases. The difference pattern is shown below the observed pattern. (d) Sectional drawing of a single Ag@FeCo@Ag NP showing its internal structure. Black and white arrows denote the direction of spins in antiferromagnetic and ferromagnetic phases, respectively. (e) Magnetization curves in the range of -10 to $10 \mathrm{kOe}$ recorded at $5 \mathrm{~K}$, after zero-field cooling (ZFC) and field cooling (FC) procedures. The inset shows the entire magnetization curve after the ZFC procedure.

さらに, X 線回折 (X-ray diffraction, XRD), X 線光電 子分光 (X-ray photoelectron spectroscopy, XPS) おょび SQUID による精密構造解析結果から (Fig. 5a-c), FeCo シェルの表面は酸化されており, 厚さ約 $1.3 \mathrm{~nm}$ のコバ ルトウスタイト $\left(\mathrm{Co}_{x} \mathrm{Fe}_{1-x} \mathrm{O}\right)$ 層が形成されていること がわかった（Fig. 5d）。C $\mathrm{Co}_{x} \mathrm{Fe}_{1-x} \mathrm{O}$ は反強磁性相であるた め, 強磁性相 FeCo との界面で顕著な磁気交換バイアス (Fig. 5e) が発現することも見いだしている ${ }^{18)}$ 。

\section{3. 細胞内小胞の磁気分離}

細胞とそれを取り巻く環境との健全なコミュニケーシ
ヨンが損なわれることによって多くの疾患が引き起こさ れる。細胞がどのように細胞外環境と物質をやり取り し，どのように細胞内部へと伝えるのかというプロセス を分子レベルで理解することは, 病気や感染症の発症機 構を知るために大切である。そのため, 細胞内外の物質 輸送にかかわる細胞内小胞を膜夕ンパクごと選択的に単 離できる分離技術の開発は, 細胞生物学において重要な 課題の一つである。

我々は $\mathrm{Ag} @ \mathrm{FeCo} @ \mathrm{Ag}$ ダブルシェル型ナノ粒子を用い て，そのような細胞内小胞の一種であるオートファゴソ ームのイメージングと磁気分離に取り組んでいる。オー 


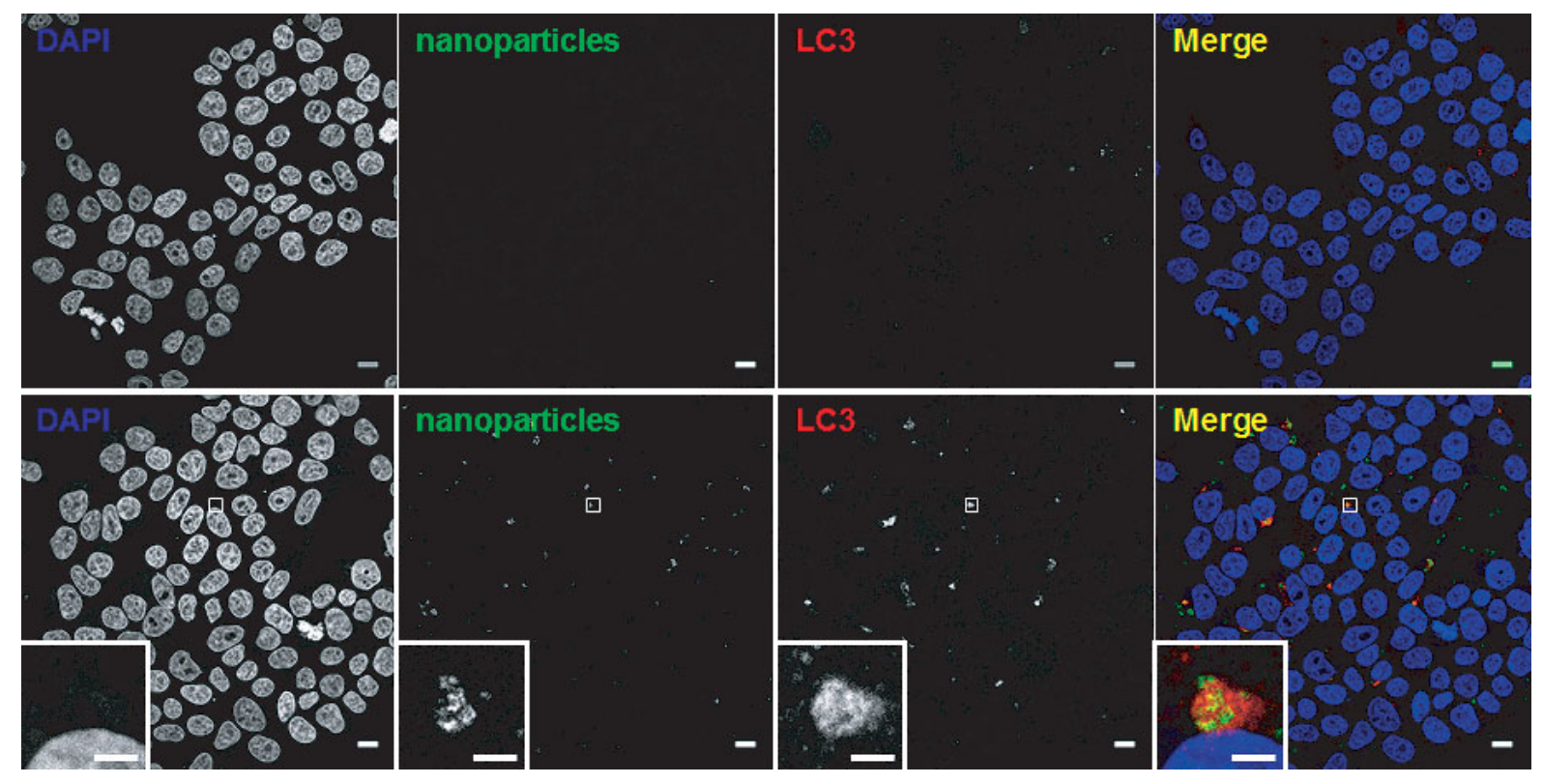

Fig. 6. (color online). Confocal laser scanning microscope images of HEK293T cells after incubation without (top) and with (bottom) Ag@FeCo@Ag NPs. Nuclei were stained by 4', 6-diamidino-2-phenylindole (DAPI) and autophagosomes were stained with mouse anti-LC3 and the Alexa594-conjugated anti-mouse antibodies. LSPR scattering image (second from the left) and corresponding merged image (the rightmost) with DAPI (the leftmost) and LC3 (second from the right) images clearly show NPs are internalized in autophagosomes. Scale bar is $10 \mu \mathrm{m}$ (scale bar in the inset is $2 \mu \mathrm{m}$ ).

トファゴソームはオートファジー（自食作用）によって 形成される細胞内小胞である。オートファジーとは，栄 養飢餓などに応じて細胞が自身の構成成分を二重の脂質 膜の小胞（オートファゴソーム）で包み込んで, リソソ ームなどの加水分解酵素を豊富に含む場に輸送し分解す る現象である ${ }^{19)}$ 。オートファゴソームの磁気分離は，オ ートファゴソームの形成からリソソームとの融合までの 間の適切な時間帯に行う必要がある。そのため我々は, リポフェクション（細胞内に物質を送達する手法の一

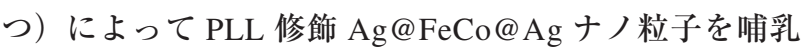
培養細胞の細胞質へ送達してオートファジーを誘導し, LSPR 散乱とLC3（オートファゴソームに特異的に局在 するタンパク質で, オートファゴソームのイメージング に広く利用されている）によるライブイメージングでオ ートファゴソームにナノ粒子が取り込まれたことを確認 後（あるいはオートファゴソームにナノ粒子が取り込ま れるのに必要な培養時間経過後), ホモジナイザーを用 いて速やかに細胞膜のみを温和に破砕し, 磁気細胞分離 装置を用いてオートファゴソームを磁気分離することを 考えた。我々は, 既に $\mathrm{Ag} @ \mathrm{FeCo} @ \mathrm{Ag}$ ナノ粒子をヒト培 養細胞 HEK293T ヘリポフェクションし, ナノ粒子がオ ートファゴソームに内包されることを確認している。 Fig. 6 に, ナノ粒子をリポフェクションしない場合（上 段）とした場合（下段）の HEK293T 細胞の共焦点顕微
鏡像を示す。なお LC3 は, マウス抗 LC3 抗体 (mouse anti-LC antibody, 一次抗体) と蛍光色素標識抗マウス抗 体 (Alexa594-conjugated anti-mouse antibody, 二次抗体) によって染色した。ナノ粒子をリポフェクションしなか った場合には LC3 は観察されないが, ナノ粒子をリポ フェクションした場合はナノ粒子の周囲を LC3 が覆っ ていることがわかる。このことはナノ粒子が細胞質へ送 達されたことでオートファジーが誘導され, ナノ粒子を オートファゴソームが包み込んでいることを示唆してい る。今後, オートファゴソームを磁気的に単離し, タン パク質の網羅的解析を行い, どのような膜タンパク質が オートファゴソームに存在しているのかを明らかにして いく予定である。

近年, 大隅良典教授 (現東工大特任教授) らによって 酵母のオートファジー関連遺伝子群の同定が成功したこ とをきっかけにオートファジーの機構の解明が進んでは いるものの ${ }^{19)}$, 分子レベルでの完全な理解のためにはオ ートファゴソームを単離し, オートファゴソームに存在 するタンパク質を同定することが最も直接的かつ確実な 方法である。また, 細胞内小胞を磁気分離することを目 的とした本技術は，オートファゴソームだけでなくエン ドソームや他の細胞内小器官の単離にも応用できるた め, タンパク質のミスフォールディングを原因とする疾 病の医薬開発への多大な貢献が期待できるほか, 肥満や 
老化を防止する医療技術にも繋がる可能性を秘めてい る。

\section{4. ま め}

磁性ナノ粒子を活用したナノ磁気医療技術は近年益々 重要性を増している。しかし，その本格的実用化には， 多機能磁性ナノ粒子の合成と表面機能化に始まり, タン パクや細胞とナノ粒子との反応制御，ナノ粒子の検出 · 操作システムの構築といった分野横断的な技術開発が必 須となる。本稿では, 磁性と局在表面プラズモン特性を 兼ね備えた $\mathrm{Ag} @ \mathrm{FeCo} @ \mathrm{Ag}$ ダブルシェル型ナノ粒子の化 学合成と表面修飾について概説した。また, その用途の 一つとして, 細胞内小胞の一種であるオートファゴソー ムの磁気分離への利用について紹介した。

\section{文献}

1) Y. Ma, S. Tong, G. Bao, C. Gao and Z. Dai : Biomaterials 34, 7706 (2013).

2) P.S. Mackay, G.J. Kremers, S. Kobukai, J.G. Cobb, A. Kuley, S.J. Rosenthal, D.S. Koktysh, J.C. Gore and W. Pham : Nanomedicine 7, 489 (2011).

3) S.K. Yen, D. Jańczewski, J.L. Lakshmi, S.B. Dolmanan, S. Tripathy, V.H.B. Ho, V. Vijayaragavan, A. Hariharan, P. Padmanabhan, K.K. Bhakoo, T. Sudhaharan, S. Ahmed, Y. Zhang and S.T. Selvan : ACS Nano 7, 6796 (2013).

4) P.H. Zhang, J.T. Cao, Q.H. Min and J.J. Zhu : ACS Appl. Mater. Interfaces 5, 7417 (2013).

5) P. Sharma, S. Brown, G. Walter, S. Santra and B.
Moudgil : Adv. Colloid Interface Sci. 123-126, 471 (2006).

6) E. Petryayeva, W.R. Algar and I.L. Medintz: Appl. Spectrosc. 67, 215 (2013).

7) J. Wang, X. Yu, S.V. Boriskina and B.M. Reinhard : Nano Lett. 12, 3231 (2012).

8) H. Mollasalehi and R. Yazdanparast : Biosens. Bioelectron. 47, 231 (2013).

9) Y.H. Xu, J. Bai and J.P. Wang : J. Magn. Magn. Mater. 311, 131 (2007).

10) Y. Lee, M.A. Garcia, N.A.F. Huls and S. Sun : Angew. Chem., Int. Ed. 122, 1293 (2010).

11) A. Mezni, I. Balti, A. Mlayah, N. Jouini and L.S. Smiri : J. Phys. Chem. C 117,16166 (2013).

12) J.S. Choi, Y.W. Jun, S.I. Yeon, H.C. Kim, J.S. Shin and J. Cheon : J. Am. Chem. Soc. 128, 15982 (2006).

13) T. Sourmail : Prog. Mater. Sci. 50, 816 (2005).

14) K. Aslan, J.R. Lakowicz and C.D. Geddes : Curr. Opin. Chem. Biol. 9, 538 (2005).

15) R. Sachan, A. Malasi, J. Ge, S. Yadavali, H. Krishna, A. Gangopadhyay, H. Garcia, G. Duscher and R. Kalyanaraman : ACS Nano 8, 9790 (2014).

16) M. Takahashi, P. Mohan, A. Nakade, K. Higashimine, D. Mott, T. Hamada, K. Matsumura, T. Taguchi and S. Maenosono : Langmuir 31, 2228 (2015).

17) K. Matsumura and S.H. Hyon : Biomaterials 30, 4842 (2009).

18) M. Takahashi, P. Mohan, D. Mott and S. Maenosono : J. Magn. Magn. Mater. 401, 339 (2016).

19) N. Mizushima, T. Yoshimori and Y. Ohsumi : Annu. Rev. Cell Dev. Biol. 27, 107 (2011). 